\title{
When the going gets tough: Entrepreneurial resilience in the context of venture failure
}

\begin{abstract}
The paper explores entrepreneurial resilience in the context of venture failure. We implement a qualitative, narrative research design and present a collective story of seven entrepreneurs' resilience in the face of venture failure. Findings reveal that entrepreneurs used cognitive and behavioral mechanisms to deal with problems resulting from failure. Furthermore, findings reveal an unexpected positive outcome from venture failure - the entrepreneurs reported feeling more resilient after failure than they felt before failure. Overall, the paper provides a rich description of 'how' the entrepreneurs developed and sustained resilience to deal with this difficult life event. These 'how' findings extend our understanding of entrepreneurial resilience by suggesting that there may be a process underlying the specific dimensions of entrepreneurial resilience identified in the current literature.
\end{abstract}

\section{Keywords:}

Entrepreneurial resilience, venture failure, narrative approach 


\section{When the going gets tough: Entrepreneurial resilience in the context of venture failure}

Scholars are beginning to acknowledge the crucial role of resilience in

entrepreneurship (Hayward, Forster, Sarasvathy \& Fredrickson 2010; James \& Gudmundsson, 2011; Hayek 2012; Ryan 2012). Empirical findings reveal that resilience enables

entrepreneurs to survive business downturns (Loh \& Dahesihsari, 2013), cope with the early stages of an innovation process (Richtner \& Sodergren, 2008), and deal with the difficulties of business start-ups (Sun, Buys, Wang \& McAuley, 2011). Furthermore, studies find resilience has a strong and positive impact on entrepreneurial intentions and influences decision making and self efficacy in dangerous environments such as places affected by war and terrorism (Bullough, Renko \& Myatt, 2014).

Despite this promising research, there is little known about the role of resilience in the specific context of venture failure. This is surprising because empirical research shows failure can lead to serious psychological, social, and financial costs for entrepreneurs (Cope, 2011; Singh, Corner, \& Pavlovich, 2007; Ucbasaran, Shepherd, Lockett \& Lyon, 2013) which preclude them from starting up future ventures (Politis \& Gabrielsson, 2009; Hayward et al. 2010). Venture founding after failure contributes to economic growth and is the focus of policy making for the European Union and others (European Commission Enterprise and Industry Group, 2011). However, such policies are unlikely to have the desired effect if entrepreneurs do not have sufficient resilience to move past the serious negative outcomes of failure outlined above. It thus seems important to investigate entrepreneurial resilience in the specific context of venture failure.

The purpose of this paper is to empirically explore entrepreneurs' resilience in the midst of venture failure. We seek to understand how entrepreneurs adapt to the damaging effects of failure and develop capacities to move through and beyond what has been described as a stigmatizing (Singh, Corner, \& Pavlovich, 2015) and overwhelmingly negative life event 
(Ucbasaran et al., 2013). We thus address the research question, "How are entrepreneurs resilient when dealing with venture failure?" We examine the question from the point of view of the lived experience of actual entrepreneurs. Moreover, we view resilience as a developable capacity that can be weakened by the serious setbacks of life; not as a stable trait (Richtner \& Sodergren, 2008). We implement a qualitative, narrative approach to examine this question. This approach enables a rich description of entrepreneurial resilience that stands in contrast to existing research which employs quantitative testing of resilience dimensions originally developed in the fields of health and psychology. We contend that the rich and comprehensive evidence yielded through qualitative design is likely to reveal idiosyncrasies in entrepreneurial resilience that are not surfaced by adapting scales from other contexts. Our design thus enables the development of resilience concept indigenous to entrepreneurship; avoiding the limits inherent in prior theory developed in other contexts (Suddaby, Bruton, \& Si, 2015). In the following sections, we present background literature, describe the research methods used, present findings, and discuss implications for the wider entrepreneurship literature.

\section{BACKGROUND}

Resilience is defined as the "ability to persist in the face of challenges and to bounce back from adversity" (Reivich, Seligman \& McBride, 2011: 25). Most resilience research was conducted in the health and psychology fields and reported how individuals adapted to a variety of adverse life circumstances such as war (Maguen et al., 2008), terrorism (Beitin \& Allen, 2005; Bonanno, Rennicke \& Dekel, 2005; Fredrickson, Tugade, Waugh \& Larkin, 2003), illness (Bellin \& Kovacs, 2006; Greeff, Vansteenwegen \& Ide, 2006; Jonker \& Greeff, 2009; Retzlaff, 2007), poverty (Li, Nussbaum \& Richards, 2007) and major disasters (Walsh, 2007). The purpose of these studies was to understand how resilience minimized negative personal outcomes from exposure to difficult circumstances and to gain insight into the design 
of intervention programs that would develop resilience (Eye \& Schuster, 2000). While earlier studies described resilience as a trait that an individual either had or didn't have, more recent research recognizes resilience as a capacity all can develop (Masten, 2001). However, there is no agreed on set of resilience dimensions nor situations demanding resilience, despite resilience being examined in a wide range of difficult life contexts (Luthans, Vogelgesang \& Lester, 2006). Scholars thus recommend further research on resilience for different populations and contexts in order to reveal the full breadth of the concept (Bonnano, Moskowitz, Papa \& Folkman, 2005).

In the past decade, management scholars started to explore resilience (Moenkemeyer Hoegl \& Weiss, 2012). This research focused mostly at the organizational level and explored how organizations stay resilient in the face of complex and challenging circumstances such as natural disasters, extreme weather conditions, terrorism, internet crime, recession, and disruptive technologies (Dervitsiotis, 2003; Foster \& Dye, 2005; Linnenluecke \& Griffiths, 2010; Sheffi \& Rice-Jr., 2005). Such disruptive circumstances can make it difficult even for well established organisations to survive and maintain performance. This led to scholars calling for further research at the individual level because it is crucial for employees to be able to adapt to changes if the organization itself is to remain resilient (Wanberg \& Banas, 2000). Organizational members must be resilient or they compromise firms' chances to survive and flourish after a crisis (Bardoel et al., 2014; Lengnick-Hall, Beck, \& LengnickHall, 2011). At the individual level, research examined resilience of leaders (Hunter 2006; Harland, Harrison, Jones \& Reiter-Palmon, 2004; Stewart \& O’Donnell, 2007) and of employees in their careers (Arora \& Rangnekar, 2014; London, 1983).

With respect to entrepreneurship research specifically, scholars are beginning to explore entrepreneurial resilience. There are only a few empirical studies to date and, broadly speaking, they can be distinguished by two different purposes. The first purpose is to identify 
measurable dimensions of resilience that pertain to entrepreneurs in particular. The approach scholars have taken is to implement dimensions of resilience from health and psychology studies of resilience and test them with a sample of entrepreneurs (see Ayalo \& Manzano, 2014; Moenkemeyer, Hoegle \& Weiss, 2012; Sun et al., 2011; Vries \& Shields, 2006). For example, Ayala and Manzano (2014) examined the dimensions of hardiness, resourcefulness, and optimism in a longitudinal study of Spanish entrepreneurs using scales originally developed by Connor and Davidson (2003) in a health context. These studies are generally quantitative in nature (Ayala \& Manzano, 2014; Bullough \& Renko, 2013; Sun et al., 2011) and have clearly added to our knowledge of dimensions of resilience from health research that are valid for entrepreneurs. Our intention is to complement this knowledge with rich information on resilience indigenous to the entrepreneurial context.

The second purpose reflected in existing entrepreneurial resilience research is to link resilience to concepts of importance in entrepreneurship research like opportunity assessment (Dewald \& Bowen, 2010); entrepreneurial decisions (Bullough et al., 2014); entrepreneurial intentions (Bullough \& Renko, 2013); and venture outcomes like growth (Sun et al., 2011). These studies also are predominantly quantitative and employ unusual samples that reflect participants who need to be resilient including entrepreneurs living in war zones (Bullogh et al., 2013); facing disruptive innovation (Dewald \& Bowen, 2010); and coping with their societies' restrictions based on gender (females) (Loh \& Dahesihsari, 2013). All told, evidence is accumulating that resilience does influence concepts that are of key importance in the field of entrepreneurship.

However, we see two important limits to existing research on entrepreneurial resilience. One is that the bulk of the research examines the resilience of entrepreneurs with successful, established businesses or intending to start up a venture. Therefore we know little about entrepreneurs' resilience when ventures fail. Given that 50 percent of small venture 
start ups are estimated to fail within the first five years of existence (Pinfold, 2000), this lack of research means we know little of resilience in a large and significant part of the phenomenon of entrepreneurship - venture failure. Furthermore, we contend that failure is perhaps more challenging than starting up and requires more resilience because it wipes out the promise of perceived entrepreneurial opportunities and throws an entrepreneur's life into a demoralizing reality of professional crisis and personal turmoil (Smith \& McElwee, 2011, Singh et al. 2007, Cope, 2011). Scholars have gone as far as to say that failure can "discourage even the most resilient of individuals" (Shepherd, Covin \& Kuratko, 2009: 598) which is understandable given the stigma entrepreneurs report experiencing (Singh et al., 2015).

The second limitation is that the bulk of empirical research on resilience in entrepreneurship has relied on quantitative methods testing dimensions of resilience imported from health and psychology research, as already stated. While these studies corroborate dimensions from other contexts, there may well be elements of resilience that are unique to the entrepreneurial context. We point to qualitative methods as an excellent approach for identifying what may be idiosyncratic about resilience for entrepreneurs. Qualitative methods are particularly suitable for overcoming "ideational ruts and cul-de-sacs of prior theories" (Suddaby, Bruton, Si, 2015:2). We therefore implement a qualitative, narrative approach to examine the research question: "How are entrepreneurs resilient in dealing with venture failure?" We contend that qualitatively examining the role of resilience in the context of entrepreneurial failure may reveal fresh insights and enhance our understanding of how entrepreneurs overcome the challenges of failure, recover from its setbacks, and move on to new beginnings which may include the new venture founding policy makers are hoping to inspire. 


\section{RESEARCH METHOD}

\section{Research Design and Context}

A qualitative research design, using a narrative approach was implemented in this study so that rich descriptions of entrepreneurial resilience could be identified (Elliot, 2005; Richards, 2009). Qualitative research is advised when a complex phenomenon such as resilience needs to be explored in depth and the focus is on understanding the meaning that participants assign to it (Creswell, 2013). Hence, narrative inquiry is appropriate for this form of research because it captures a sequence of events from the participants point of view (Endres and Woods, 2007; Warren, 2004) in order to produce "rich, thick data" (Willis, 2006: 272). People make sense of their experiences and elaborate their opinions and reasons for their actions and intentions through a process of interpretation (Lawler, 2002; Shkedi, 2005; Richardson, 1990). Narratives are therefore somewhat unique in that they facilitate the understanding of how a sequence of events may unfold over time and how they may impact on the people involved (Polkinghorne, 2003). In this study, narratives reveal how the entrepreneurs' resilience enabled them to deal with the aftermath of venture failure, and reconstitute their future career aspirations. We thus collected and analyzed entrepreneur's narratives related to developing resilience to examine the research question, "How are entrepreneurs resilient when dealing with venture failure?"

This study took place in New Zealand (NZ) which is a somewhat unique context in that it is ranked third in terms of global entrepreneurial activity. The Global Entrepreneurial Monitor Report of 2005 (the latest global data available for this country) ranks New Zealand's entrepreneurial activity as $17.6 \%$, higher than the global average of $9.1 \%$ and the USA which is in sixth position at $12.4 \%$ (Fredrick and Chittock, 2006: 22). Innovation is a key feature of New Zealand's culture, with a higher proportion of entrepreneurs founding ventures due to having an ability to exploit perceived business opportunities rather than starting businesses 
based on necessity (Samujh 2009: 132). However, higher rates of entrepreneurial activity do not necessarily suggest greater entrepreneurial expertise, and New Zealand's higher than average venture failure rates (Lee, Peng \& Barney, 2011) stem from a number of factors that discourage success. It has a regulatory environment that is not supportive of failure with liquidation being the most common outcome of insolvency (Kuruppu, Laswad \& Oyelere, 2003). This is contrasted with the debtor-oriented approach in the USA, where failing businesses are encouraged to continue operating their way out of insolvency (Franks, Nyborg \&Torous, 1996). New Zealand's egalitarian values also breed a cultural incongruity called the "tall poppy syndrome" (TPS) where envy and even some hostility can be directed towards those who are successful (Kirkwood, 2007).

\section{Sampling and Data Collection}

Purposive sampling was used (Patton, 1990) that enabled us to find seven participants with information-rich stories on resilience in dealing with venture failure, the phenomenon being examined. Given that failure research is difficult in terms of accessibility and willingness of entrepreneurs to share their experiences (Cope, 2011; Shepherd, Wiklund \& Haynie, 2009; Zacharakis Meyer \& DeCastro, 1999), like Cope (2011), we used snowballing technique to identify entrepreneurs likely to provide rich information for the purpose of our study (Patton, 1990). Further information on the participants and their failed ventures is outlined in Table 1. Pseudonyms were given to the participants to protect their anonymity. Data was collected using interviews as recommended for narrative research (Creswell, 2013; Elliot 2005). The semi-structured interviews lasted between 1.5 and 2 hours to ensure finegrained information was recorded about entrepreneurs' lived experience of venture failure and their resilience in dealing with its aftermath. Secondary data was also collected from media articles, websites, email communication, and notes from phone conversations with the participants but this served as background data to help verify the sequence of events revealed 
through interviews (Creswell, 2013). For all participants in the sample, the failed venture was the first venture they founded and therefore it was also their first venture failure.

Insert Table 1 about Here

\section{Data Analysis}

We began data analysis by constructing a sequential chronology of events for each of the entrepreneurs stemming from the transcripts (Creswell, 2013). The chronology as well as an initial reading of transcripts suggested small, initial set of open codes like "resilience" and "consequences of venture failure". Next, we used margin notes and analytical memos produced during subsequent multiple readings of transcripts to expand these open codes into more detailed codes such as "decisions and behaviors around failure" and "links between resilience and failure" (Richards, 2009; Lieblich, Tuval-Mashiach \& Zilber, 1998). We identified resilience themes by abstracting patterns in the failure and resilience experiences of the participants (Morse \& Richards, 2002; Creswell, 2007; Miles \& Huberman, 1994). We paid particular attention to any novel or surprising insights and assessed emerging themes by ascertaining whether there was sufficient clear evidence in the data to support them. This process enabled us to identify a collective story (Richardson, 1990) that illustrated how entrepreneurs' resilience enabled them to deal with and move on from venture failure. The following findings section presents the collective narrative.

\section{FINDINGS}

How are entrepreneurs resilient when dealing with venture failure? We present a collective narrative of seven entrepreneurs' resilience in the face of failure which scholars have described as a major, life altering (Ucbasaran et al., 2013) stigmatizing event (Singh et al., 2015). The collective narrative is comprised of a prologue, story of resilience, and epilogue and ultimately provides a rich description of resilience that has not been revealed by 
quantitative studies examining dimensions originally developed in health and psychology research. It thus provides insights on resilience indigenous to the entrepreneurship context.

\section{Prologue}

We provide a prologue which describes the havoc that venture failure wrought in the lives of participants; thereby providing background to the upcoming story of resilience. This rich description is depicted in Table 2 and shows the financial, social, psychological, and health issues that participants experienced with the demise of their ventures. The prologue reveals not only the dire financial situation that the participants and their families experienced, but also the debilitating sense of hardship, loss, and anxiety that seeped into other aspects of their lives. As Natalie put it, "I could probably go on all day telling how many things were affected by failure".

Insert Table 2 About here

\section{Story of Resilience}

The story of resilience is revealed in three themes that surfaced from evidence and shows how participants stayed resilient as they confronted and dealt with their changed circumstances despite the overwhelming experience described in the prologue and corroborated in other research on entrepreneurial failure (Shepherd, 2003; Ucbasaran et al., 2013). The three themes include challenging experiences, daily steps, and big picture.

Challenging Experiences. Participants evoked models of getting through challenging situations in the past in order to be resilient in the midst of venture failure. Two participants created models from the deaths of loved ones in order to remind themselves how to move through the extreme pain of great loss and on get on with life. For example, Natalie poignantly used her mother's death to assure herself that the pain of failure would ultimately end. She was able to remind herself that losing her mother was initially extremely painful 
and felt like a "free fall" that would never end. However, with the passing of time she realized that even this profound pain "had a bottom" and when "one reaches that bottom then one stops hurting and gets up to go on'. She worked to "harden" herself to the reality of venture failure as she had "hardened a bit" with the loss of her mother at a very young age and "learnt to move on" as she parented her siblings after her mother died.

Similarly, Francesca invoked the model of her parents' deaths to help her stay strong during venture failure. The loss of her parents when she was still a teenager was devastating but she reminded herself that she "got through from adolescence to adulthood" just fine without "an adult hand" to guide her. She thus was able to retain that hope that she would make it through the similarly devastating experience of venture failure equally well. She also recalled the challenge of caring for her terminally ill husband for 10 years as he slowly died after a stroke. She described these years as "ghastly", "heartbreaking and dreadful". She remembered how she was able to deal with her husband's death because she felt the presence of God like a "supportive parent" in her life. These examples that equate loss of a loved one with demise of a venture corroborate Shepherd's (2003) conceptual research that says the grief from these two life events is analogous.

Two participants drew on the challenge of difficult childhoods in order to stay resilient in the face of venture failure. For example, Luke continually reminded himself that he had grown up in "financial hardship" and had also faced financial difficulties when settling in a new country. He described his situation as "having no money and not knowing anyone". Revisiting these experiences reminded him that he "was more resilient than most people were" and kept him positive about the difficulties he faced as his venture failed. He believed that he had a unique capacity to progress through failure without giving into the negativity of it because he knew hardship first-hand while "many people do not know what hardship is". He 
told himself that even though venture failure was depressing, "something positive will happen", consistent with his memories of overcoming previous hardships.

Finally, two participants drew on their memories of others dealing with hardships. For example, Ethan remembered his mother patiently soldering on caring for her children and working long hours to meet the most basic family needs due to extreme financial hardship. He reminded himself that his mother ultimately lived in a "two million dollar mansion" in her later years and this gave him hope while dealing with venture failure that he would work his way out of failure towards much better circumstances. Ethan coached himself to "keep on track and keep working hard" like his mother did. Also, Hayden recalled the autobiographic account of a renowned and successful entrepreneur - how this entrepreneur had relentlessly pursued his venturing vision despite number of setbacks, such as when he sold his wife's jewellery to support expenses.

Daily steps. This second theme illustrates how entrepreneurs took steps daily in order to engage with the very difficult failure episode in their lives as a strategy to move through the challenges presented. Interestingly, daily steps fell into two categories: cognitive and behavioral. Cognitively, entrepreneurs created devices to help them move through and beyond the difficulties brought on by failure. For example, Ethan used the analogy of building a house daily to remind himself he had to keep moving ahead building a life after failure. He said, "When you build a house, you build the walls first, and then when you can manage, you build one room then another but it's important to keep building to complete the house". Similarly, Luke followed the advice of a friend and mentally created "two boxes". When negative thoughts about his venture failure surfaced he placed those in the "old box" and placed ideas about what he could do to re-invent his life in the "new box". Luke reported focusing more and more on the "new box", once he had this mental distinction, and found it a powerful turning point that enabled him to manage the negative thoughts of failure and their 
associated stress. Also, Morgan wrote daily in a journal which he described as "a simple yet powerful process" to release his "bottled up feelings" about failure. This daily ritual provided an avenue to surface his feelings about failure and ultimately led him to seek the help of another person. The other person further facilitated Morgan's awareness of the grief he was experiencing and the release of much of it. Uma's cognitive device was a resolution: She resolved to keep going daily even though she had to "drag herself out of bed every morning to get on with solving problems". She did this despite knowing it was "not going to be a good day”. She explained how making such a resolve was very difficult at first but over time it had what she called a "snowball effect" in that it channeled her energy into finding solutions to problems instead of dwelling on the negative aspects of failure.

Behaviorally, entrepreneurs filled the void left by venture loss with new activities that would force them to keep busy in daily life. For example, Uma and her husband/ coentrepreneur purchased and renovated what she described as a "derelict" property. They had very little money but they could buy the property for next to nothing, keep busy, and hopefully sell it for more than they purchased it for. She described this as a "gamble" but also a way to fill the "emptiness" of her days which had previously been extremely busy with the venture. Another reason she purchased the property was to create something for her husband to do, he had been her business partner and was a loose ends when the business failed. Ethan attended conferences and went to meetings with people involved in developing the crumb rubber technology that he planned to use when restarting his failed venture. Morgan enrolled for a post-graduate qualification in business and Natalie took an accounting course. Hayden spent many of his spare hours networking and seeking partners for the next venture he planned to start.

Big picture. Participants reminded themselves of the big picture of their lives in order to move through the negativity of venture failure and get on with life. For many of the 
entrepreneurs, family was the big picture that kept them engaged with life in a positive way; providing an avenue for moving through the negativity of failure ultimately into new, more positive chapters in their lives. In particular, having family to look after and provide for shifted their focus from defeating thoughts of failure to proactively dealing with their problems. For example, Luke said that "people closest to him made him resilient". He "wanted to make sure that his daughter went to a good school" and this made him "get up and leave the bed each morning" to resolve the aftermath of his failed venture and put his family back on track. Similarly, Natalie's need to look after and set a good example for her son helped her move on after failure. She wanted to show her son how to be a "good citizen" so she continued dealing with the multiple problems that surrounded her after failure instead of collapsing into depression and denial. Morgan decided to focus on saving his marriage and being there for his young children. He deliberately chose this focus over an opportunity to be involved in a new venture. Luke also talked about how he worked to ensure that his family had a stable source of income.

Ethan articulated a big picture that was beyond his family, although he also mentioned his family as a priority. He had a strong environmental vision and wanted to start up another tire recycling business in the future as part of this vision. He thus stayed resilient by working on the technology that he thought would be the core of this business. He thought of this technology as a seed that could be nurtured over time and grown into a strong business that would contribute environmental value. This vision inspired him to spend much on moving the technology and plans forward for his new business.

\section{Epilogue}

The collective narrative is completed with an epilogue, in order to provide a resolution to the narrative (Selden \& Fletcher, 2010). The epilogue gives a sketch of entrepreneurs' lives once they had dealt with the aftermath of failure, including most of the social, 
psychological, and physical issues the failure engendered. Previous studies have shown that venture failure is a depleting experience for entrepreneurs (Shepherd, 2003; Singh et al., 2007; Ucbasaran et al. 2013). However, the epilogue presented in Table 3 gives a thick description of how entrepreneurs unanimously felt they were more resilient than before failure.

Participants indicated they were better prepared to take on any future setbacks that life threw at them.

Insert Table 3 about Here

\section{DISCUSSION AND CONCLUSION}

The purpose of this paper was to empirically explore entrepreneurial resilience in dealing with venture failure. We saw venture failure as an excellent context to gain further understanding of entrepreneurial resilience because studies have shown that failure leads to serious negative life changing outcomes (Cope, 2011; Singh et al., 2007, Ucbasaran et al., 2013) and can be so demoralizing that it deters entrepreneurs from ever starting up another venture (Politis \& Gabrielsson, 2009). We thus addressed the research question "How are entrepreneurs resilient in dealing with venture failure?" The findings revealed a collective narrative wherein entrepreneurs used cognitive and behavioral mechanisms to remain resilient when dealing with the serious financial, social, psychological and health problems that resulted from venture failure. These mechanisms included the three overarching themes of modeling on previous challenging experiences, taking daily steps, and continually remembering the big picture of their lives. These findings present a rich picture of the process whereby entrepreneurs develop and sustain resilience in order to move through and beyond venture failure. This picture provides important insight into the "how" of entrepreneurial resilience - it identifies particular mechanisms used by entrepreneurs to develop resilience in the face of a very difficult life event. We suggest that these "how" 
findings begin to reveal the process that underlies the "what" of the specific dimensions of entrepreneurial resilience revealed in existing literature. For example, the "how" themes revealed here may be the process mechanism whereby entrepreneurs build the hardiness (Ayala \& Manzano, 2014), optimism (Ayala \& Manzano, 2014), creativity and flexibility (Sun et al., 2011) dimensions of resilience reported in existing research.

We also reported a positive outcome for entrepreneurs that were unexpected given the overwhelmingly negative outcomes for failed entrepreneurs reported in the literature (see Shepherd et al., 2009; Singh et al., 2007; Smith \& McElwee, 2011; Ucbasaran et al., 2013). In particular, entrepreneurs reported feeling more resilient after failure than they had felt before failure. Although this finding must be considered a preliminary one given the exploratory nature of the research, we recommend future research that explicitly tests differences in entrepreneurs' resilience before and after venture failure. Moreover, we hope that this surprising finding encourages other researchers to conduct future research intent on surfacing other positive outcomes that may result from venture failure.

Overall, the study has two implications for the wider entrepreneurship literature. First, findings have implications for research on the self-regulation of emotions and thoughts in the midst of entrepreneurial failure. As stated, current evidence shows entrepreneurs using particular mechanisms that could be seen as self-regulation including the cognitive daily steps and modeling of challenging experiences. Entrepreneurs thus chose to engage in selfenabling instead of self-debilitating self-talk to develop resilience in the face of a setback in life (Bandura, 1991). As such, findings encourage the application of self-regulation theory (Bandura, 2001) to the context of venture failure. Scholars could examine the effect of entrepreneurs' individual differences in self-regulation on outcomes such as time to recover from the loss of failure, willingness to found future ventures, as well as learning from failure. The fact that our participants engaged in self-enabling self-talk inspires us to agree with 
Ucbasaran et al. (2013) that there is scope for future research that draws on positive psychology to consider positive outcomes such as personal growth as an outcome of entrepreneurial failure.

Second, findings have implications for the well documented outcomes of venture failure including social costs such as loss of important relationships (Cope, 2011; Ucbasaran et al., 2013), lack of confidence in the future (Politis \& Gabrielsson, 2009), and hesitation about risks (Politis \& Gabrielsson, 2009). As already stated, the failure literature predominantly identifies negative outcomes. However, the unexpected positive outcome of enhanced resilience encourages future research that examines the effects of self-enabling mechanisms on these well-known negative outcomes. In particular, scholars could investigate the influence of modeling challenging experiences on lack of confidence. We conjecture that entrepreneurs who make use of modeling of challenging experiences might actually gain in confidence because they have learned how to stay resilient through the very debilitating experience of venture failure.

As with any research, our findings must be considered against the background of possible limitations of this research. The first limitation is that even though our study provided rich insights into entrepreneurial resilience in the context of venture failure, the data was collected in only one country - New Zealand. Given that scholars have found national level cultural differences towards entrepreneurial failure, (Begley \& Tan, 2001; Cave, Eccles \& Rundle, 2001; Damaraju, Barney \& Dess, 2010), our findings may not be generalizable to entrepreneurs in other countries. Hence we recommend that further studies be carried out in other national contexts. The second limitation is that our study explored resilience of first time entrepreneurs experiencing their initial venture failure. It would be valuable to examine how resilience is affected in the context of multiple failures. Does it get easier to stay resilient when dealing with failure if entrepreneurs have previous failure experience? Overall, 
our paper extends our understanding of venture failure by highlighting how entrepreneurs stayed resilient when dealing with failure. Specifically, finding ways to be resilient in the midst of everyday challenges of venture failure enabled entrepreneurs to not only deal with their ongoing problems but also fortify their capacity to be resilient in dealing with future setbacks. 


\section{REFERENCES}

Arora, R., \& Rangnekar, S. (2014). Workplace Mentoring and Career Resilience: An Empirical Test. The Psychologist-Manager Journal, 17(3): 205-220.

Ayala, J.-C., \& Manzano, G. 2014. The resilience of the entrepreneur. Influence on the success of the business. A longitudinal analysis. Journal of Economic Psychology, 42: 126-135.

Bandura, A. 1991. Social cognitive theory of self-regulation. Organizational Behavior and Human Decision Processes, 50: 248-287.

Bandura, A. 2001. Social cognitive theory: An agentic perspective. Annual Review of Psychology, 52: 1-26.

Bardoel, E. A., Michelle, T., Cieri, H. D., \& McMillan, L. 2014. Employee resilience: an emerging challenge for HRM. Asia Pacific Journal of Human Resources, 52: $297-$ 297.

Begley, T.M., Tan, W-L., 2001. The socio-cultural environment for entrepreneurship: A comparison between East Asian and Anglo-Saxon Countries. Journal of International Business Studies, 32(3): 537-553.

Beitin, B. K., \& Allen, K. R. 2005. Resilience in Arab American couples after September 11, 2001: A systems perspective. Journal of Marital and Family Therapy, 31(3): 251267.

Bellin, M. H., \& Kovacs, P. J. 2006. Fostering resilience in siblings of youths with a chronic health condition: A review of literature. Health \& Social Work, 31(3): 209-216.

Bonanno, G. A., Papa, A., Moskowitz, J. T., \& Folkman, S. 2005) Resilience to loss in bereaved spouses, bereaved parents, and bereaved gay men. Journal of Personality and Social Psychology, 88(5), 827-843.

Bonanno, G. A., Rennicke, C., \& Dekel, S. 2005. Self enhancement among high - exposure survivors of the September 11th terrorist attack: Resilience or social maladjustment? Journal of Personality and Social Psychology, 88(6): 984-998.

Bullough, A., \& Renko, M. 2013. Entrepreneurial resilience during challenging times. Business Horizons, 56: 343-350.

Bullough, A., Renko, M., \& Myatt, T. 2014. Danger Zone Entrepreneurs: The importance of resilience and self-efficacy for entrepreneurial intentions. Entrepreneurship Theory and Practice, 38(3): 1-27

Calvo, J. C. A., \& Garcia, G. M. 2010. Established business owners' success: Influencing factors. Journal of Developmental Entrepreneurship, 15(3): 263-286.

Cave, F. D., Eccles, S.A., Rundle, M., 2001. An exploration of attitudes to entrepreneurial failure: a learning experience or an indelible stigma? Proceedings of the 2001 Babson 
College-Kauffman Foundation Entrepreneurship Research Conference: Jonkoping, Sweden, May.

Cope, J., 2011. Entrepreneurial learning from failure: An interpretive phenomenological analysis. Journal of Business Venturing, 26(6): 604-623.

Connor, K. M., \& Davidson, J. R. T. 2003. Development of a new resilience scale: The Connor-Davidson Resilience Scale (CD-RISC). Depression and Anxiety, 18: 76-82.

Creswell, J.W., 2007. Qualitative Inquiry \& Research Design: Choosing Among Five Approaches (2 $2^{\text {nd }}$ ed.). Thousand Oaks, CA: Sage

Creswell, J. W. 2013. Qualitative inquiry and research design: Choosing among five approaches (3 Ed.). Thousand Oaks, CA: Sage.

Damaraju, N.L., Barney, J., Dess, G., 2010. Stigma and entrepreneurial risk taking, http://www2.druid.dk/conferences/viewpaper.php?id=502023\&cf=43, Accessed $15^{\text {th }}$ November 2012.

Dervitsiotis, K. N. 2003. The pursuit of sustainable business excellence: Guiding transformations for effective organizational change. Total Quality Management, 14(3): 251-267.

Dewald, J., \& Bowen, F. 2010. Storm clouds and silver linings: Responding to disruptive innovations through cognitive resilience. Entrepreneurship Theory and Practice, 34(1):197-218.

Elliot, J., 2005. Using Narrative in Social Research: Qualitative and Quantitative Approaches. Thousand Oaks, CA: Sage

Endres, A. M., \& Woods, C. R. 2007. The case for more "subjectivist' research on how entrepreneurs create opportunities. International Journal of Entrepreneurial Behaviour \& Research, 13(4): 222-234.

European Commission Enterprise and Industry Group, 2011. Small and medium sized enterprises: A second chance to entrepreneurs, http://ec.europa.eu/sme2chance, Accessed 15 ${ }^{\text {th }}$ November 2012.

Eye, A. V., \& Schuster, C. 2000. The odds of resilience. Child Development, 71(3): 563-566.

Foster, S. P., \& Dye, K. 2005. Building continuity into strategy. Journal of Corporate Real Estate, 7(2): 105-119.

Franks, J., Nyborg, K., Torous, W., 1996. A comparison of the US, UK and German insolvency codes. Financial Management, 25(3): 86-101.

Frederick, H., Chittock, G. 2006. Global Entrepreneurship Monitor Aotearoa New Zealand. Unitec New Zealand's Centre for Innovation \& Entrepreneurship Research Report Series, 4(1). Unitec, Auckland, New Zealand. 
Fredrickson, B. L., Tugade, M. M., Waugh, C. E., \& Larkin, G. R. 2003. What good are positive emotions in crisis? A prospective study of resilience and emotions following the terrorist attacks on the United States on September 11th, 2001. Journal of Personality and Social Psychology, 84(2): 365-376.

Greeff, A. P., Vansteenwegen, A., \& Ide, M. 2006. Resiliency in families with a member with a psychological disorder. The American Journal of Family Therapy, 34(4): 285-300.

Harland, L., Harrison, W., Jones, J. R., \& Reiter-Palmon, R. 2004. Leadership behaviors and subordinate resilience. Journal of Leadership and Organizational Studies, 11(2): 214.

Hayek, M. 2012. Control beliefs and positive psychological capital: Can nascent entrepreneurs discriminate between what can and cannot be controlled? Journal of Management Research, 12(1): 3-13.

Hayward, M. L. A., Forster, W. R., Sarasvathy, S. D., \& Fredrickson, B. L. 2010. Beyond hubris: How highly confident entrepreneurs rebound to venture again. Journal of Business Venturing, 25(6): 569-578.

Hunter, D. 2006. Leadership resilience and tolerance for ambiguity in crisis situations. The Business Review, 5(1): 44-50.

James, N., \& Gudmundsson, A. 2011. Entrepreneurship optimism and the new venture creation process. Journal of Asia Entrepreneurship and Sustainability, V11(2): 5271.

Jonker, L., \& Greeff, A. P. 2009. Resilience factors in families living with people with mental illness. Journal of Community Psychology, 37(7): 859-873.

Kirkwood, J. 2007. Tall poppy syndrome: Implications for entrepreneurship in New Zealand. Journal of Management \& Organization, 13(4): 366-382.

Kuruppu, N. Laswad, F., Oyelere, P. 2003. The efficacy of liquidation and bankruptcy prediction models for assessing going concern. Managerial Auditing Journal, 18(6/7): 577-590.

Lawler, S. 2002. Narrative in social research. In T. May (Ed.), Qualitative research in action: 242-259. London: Sage. Accessed from Ebrary Ebooks 16 May 2011.

Li, S. T., Nussbaum, K. M., \& Richards, M. H. 2007. Risk and protective factors for urban African-American youth. American Journal of Community Psychology, 39(1-2): 2135.

Lengnick-Hall, C. A., Beck, T. E., \& Lengnick-Hall, M. L. 2011. Developing a capacity for organizational resilience through strategic human resource management. Human Resource Management Review, 21: 243-255. 
Linnenluecke, M., \& Griffiths, A. 2010. Beyond adaptation: Resilience for business in light of climate change and weather extremes. Business Society, 49(3): 477-511.

Loh, J. M. I., \& Dahesihsari, R. 2013. Resilience and economic empowerment: A qualitative investigation of entrepreneurial Indonesian women. Journal of Enterprising Culture, 21(1): 107-121.

London, M. 1988. Organizational support for employees' career motivation: A guide to human resource strategies in changing business conditions. Human Resource Planning, 11(1): 23-32.

Luthans, F., Vogelgesang, G. R., \& Lester, P. B. 2006. Developing the psychological capital of resiliency. Human Resource Development Review, 5(1): 25-44.

Maguen, S., Turcotte, D. M., Peterson, A. L., Dremsa, T. L., Garb, H. N., McNally, R. J., et al. 2008. Description of risk and resilience factors among military medical personnel before deployment to Iraq. Military Medicine, 173(1), 1-9.

Masten, A. S. 2001. Ordinary magic: Resilience processes in development. American Psychologist, 56(3): 227-238.

Miles, M. B., \& Huberman, A. M. 1994. Qualitative data analysis: An expanded sourcebook. Thousand Oaks, CA: Sage.

Moenkemeyer, G., Hoegl, M., \& Weiss, M. 2012. Innovator resilience potential: A process perspective of individual resilience as influenced by innovation project termination. Human Relations, 65(5): 627-655.

Morse, J. M., \& Richards, L. 2002. Readme first for a reader's guide to qualitative methods. Thousand Oaks, CA: Sage

Lee, S.-H., Yamakawa, Y., Peng, M., Barney, J. 2011. How do bankruptcy laws affect entrepreneurship development around the world? Journal of Business Venturing, 26(5): 505-520.

Lieblich, A., Tuval-Mashiach, R., Zilber, T. 1998. Narrative Research: Reading, Analysis, and Interpretation. Thousand Oaks, CA: Sage.

Patton, M.Q. 1990. Qualitative evaluation and research methods. London: Sage

Pinfold, J. 2000. Examining venture failure rates: A New Zealand study. Small Enterprise Research, 8: 56-72.

Polkinghorne, D.E. 2003. Narrative configuration in qualitative analysis. In J.A. Hatch, \& R. Wisniewski (Eds.), Life history and narrative: 239:248. Taylor \& Francis e-library, Ebrary eBooks, 5-24, Accessed16 May 2011.

Politis, D., Gabrielsson, J., 2009. Entrepreneurs' attitudes towards failure: An experiential learning approach. International Journal of Entrepreneurial Behaviour \& Research, 15(4): 364-383. 
Reivich, K. J., Seligman, M. E. P., \& McBride, S. 2011. Master resilience training in the U.S. army. American Psychologist, 66(1), 25-34.

Retzlaff, R. 2007. Families of children with Rett syndrome: Stories of coherence and resilience. Families, Systems \& Health, 25(3): 246-262.

Richards, L. 2009. Handling qualitative data: A practical guide. Thousand Oaks, CA: Sage.

Richardson, L. 1990. Writing strategies: Reaching diverse audiences. Thousand Oaks, CA: Sage

Richtner, A., \& Sodergren, B. 2008. Innovation projects need resilience. International Journal of Technology Intelligence and Planning, 4(3):257-275.

Ryan, M. 2012. Do we have too many entrepreneurs? Beware the downside of innovation. University of Auckland Business Review, 15(1):6-14.

Samujh, R. H. (2009). New Zealand entrepreneurs: Leading for excellence. World Review of Entrepreneurship, Management and Sustainable Development, 5(2), 132.

Selden, P. \& Fletcher, D. 2010. "Practical narrativity" and the "real-time story" of entrepreneurial becoming in The Republic of Tea. Entrepreneurial Narrative Theory Ethnomethodology and Reflexivity (ENTER) 1: 51-74.

Sheffi, Y., \& Rice-Jr., J. B. 2005. A supply chain view of the resilient enterprise. MIT Sloan Management Review, 47(1): 41-48.

Shkedi, A. 2005. Multiple Case Narrative: A Qualitative Approach to Studying Multiple Populations. Philadelphia: John Benjamins Pub.

Shepherd, D. A. 2003. Learning from business failure: Propositions of grief recovery for the self-employed. The Academy of Management Review, 28(2): 318-328.

Shepherd, D. A., Covin, J., \& Kuratko, D. 2009. Project failure from corporate entrepreneurship: Managing the grief process. Journal of Business Venturing, 24(6): 588-600.

Shepherd, D. A., Wiklund, J., and Haynie, J. M., 2009. Moving forward: Balancing the financial and emotional costs of business failure. Journal of Business Venturing 24(2): 134-148.

Singh, S., Corner, P., Pavlovich, K., 2007. Coping with entrepreneurial failure. Journal of Management \& Organization, 13(4): 331-344.

Singh, S., Corner, P.D., Pavolvich, K., 2015. Failed, not finished: A narrative approach to understanding venture failure stigmatization. Journal of Business Venturing, 30 (1): $150-166$ 
Smith, R., McElwee, G., 2011. After the fall: Developing a conceptual script based model of shame in narratives of entrepreneurs in crisis! International Journal of Sociology and Social Policy, 31(1/2): 91-109.

Stewart, J., \& O'Donnell, M. 2007. Implementing change in a public agency: Leadership, learning and organisational resilience. International Journal of Public Sector Management, 20(3): 239-251.

Suddaby, R., Bruton, G. D., \& Si, S. X. 2015. Entrepreneurship through a qualitative lens: Insights on the construction and/or discovery of entrepreneurial opportunity. Journal of Business Venturing, 30:1-10.

Sun, J., Buys, N., Wang, X., \& McAuley, A. 2011. Using the concept of resilience to explain entrepreneurial success in China. International Journal of Management and Enterprise Development, 11(2/3/4):182-202.

Ucbasaran, D., Shepherd, D., Lockett, A., Lyon, S.J. 2013. Life after business failure: The process and consequences of business failure for entrepreneurs. Journal of Management, 39(1): 163-202.

Vries, H. D., \& Shields, M. 2006. Towards a theory of entrepreneurial resilience: A case study analysis of New Zealand SME owner operators. Applied Research Journal, 5(1): 33-43.

Walsh, F. 2007. Traumatic loss and major disasters: Strengthening family and community resilience. Family Process, 46(2): 207-227.

Warren, L. 2004. A systemic approach to entrepreneurial learning. Systems, Research and Behavioral Science, 21(1): 3-16.

Zacharakis, A. L., Meyer, G. D., \& DeCastro, J. 1999. Differing perceptions of new venture failure: A matched exploratory study of venture capitalists and entrepreneurs. Journal of Small Business Management, 37(3): 1-14 
Table 1

Description of entrepreneurs and failed ventures

\begin{tabular}{|c|c|c|c|}
\hline Participant & $\begin{array}{l}\text { Background \& } \\
\text { age at } \\
\text { interview }\end{array}$ & $\begin{array}{l}\text { Venture } \\
\text { Description }\end{array}$ & Reasons for Failure \\
\hline Luke & $\begin{array}{l}\text { IT professional } \\
45\end{array}$ & $\begin{array}{l}\text { Software sales started } \\
\text { with partner }\end{array}$ & $\begin{array}{l}\text { Premature decision to expand the business \& } \\
\text { dishonest actions of business partner caused heavy } \\
\text { losses \& forced venture closure }\end{array}$ \\
\hline Hayden & $\begin{array}{l}\text { Engineer } \\
44\end{array}$ & $\begin{array}{l}\text { Prawn harvesting \& } \\
\text { retail }\end{array}$ & $\begin{array}{l}\text { Sudden uncontrollable disease } \& \text { simultaneous } \\
\text { unforeseen regulatory changes led to massive } \\
\text { financial setbacks \& forced firm sale }\end{array}$ \\
\hline Ethan & $\begin{array}{l}\text { Business } \\
\text { professional } \\
60\end{array}$ & $\begin{array}{l}\text { Tire recycling \& re- } \\
\text { manufacturing through } \\
\text { crumb rubber technology }\end{array}$ & $\begin{array}{l}\text { Inefficient manufacturing technology led to } \\
\text { increased costs \& substantial financial losses. } \\
\text { Venture was on brink of bankruptcy so closed } \\
\text { down and sold assets }\end{array}$ \\
\hline Uma & $\begin{array}{l}\text { Academic } \\
53\end{array}$ & $\begin{array}{l}\text { Egg wholesale business } \\
\text { started with husband \& } \\
\text { friends }\end{array}$ & $\begin{array}{l}\text { Customers continually missing payments, sharp } \\
\text { increase in cost of feed \& subsequent cash flow } \\
\text { issues made venture financially unsustainable \& } \\
\text { forced closure }\end{array}$ \\
\hline Morgan & $\begin{array}{l}\text { Trainee in door } \\
\text { making } \\
\text { company } \\
60\end{array}$ & $\begin{array}{l}\text { Door \& window } \\
\text { manufacturing started in } \\
\text { partnership with friend }\end{array}$ & $\begin{array}{l}\text { Partner's corruption in business transactions led to } \\
\text { heavy financial losses \& unresolved conflicts that } \\
\text { forced firm closure }\end{array}$ \\
\hline Francesca & $\begin{array}{l}\text { Academic } \\
62\end{array}$ & $\begin{array}{l}\text { Manufacturing \& selling } \\
\text { of innovative pest trap in } \\
\text { partnership with friends }\end{array}$ & $\begin{array}{l}\text { Incompatibility with business partners led to poor } \\
\text { communication among venture team \& with } \\
\text { suppliers leading to closure }\end{array}$ \\
\hline
\end{tabular}

\section{Open to Future venture founding?}

Yes, already started another venture

Yes, open to starting another venture

Yes, will re-start the failed tire manufacturing venture by introducing more efficient crumb rubber technology

Yes, open to starting another venture

Yes, open to starting another venture

No, does not want to found another venture 
Table 2

\section{Description of entrepreneurs' lives during and immediately after failure}

\section{Participant Financial consequences}

Luke

Was unemployed for a few months; losing only source of family income. Lost all the money invested in the business by father \& brother.

Hayden Lost family income \& all personal savings (were invested in the business). Unemployed for more than a year, post-failure worked odd jobs for income. Slapped with legal action by creditors.

Ethan Lost $90 \%$ of personal savings invested in venture. Forced to sell property \& struggled to meet basic family needs \& mortgage payments for two years.

Uma Lost major source of income \& struggled financially for a year. Relocated to another town for work \& income opportunities.

Morgan Was unemployed \& lost the only source of family income. Found it very hard to meet family expenses for a year.

Francesca

Six years of research funding was wasted due to failure, limited her ability to secure future funding given insular NZ academic community.

Natalie Was unemployed for a year. Lost all personal savings. Could not pay rent beyond a few weeks, thought she would have to let her son go to a shelter. Had to live in sister's house.

\section{Social consequences}

Failure produced huge daily tensions in his marriage

because wife warned him about his business partner's dishonesty but he didn't confront partner about discrepancies in accounts. Wife blamed him for failure.

Close friendship with business partner ended.

While wife \& kids remained supportive, many other family relationships ended, relatives who were close during the life of the venture, washed their hands of him when he failed.

Felt socially embarrassed as news of venture failure got reported in local media.

Had daily arguments with husband (also her business partner). Both were desolate after venture failed, felt isolated without the daily venture routine \& had no social life after relocation.

Morgan's wife had her bags packed to leave him, when he came home to tell her of failure. She was leaving because he was not raising their first, new born child given time spent on venture. Lost a good friend through business partnership split \& many other friends who could not cope with his grief around failure.

Relationship with business partners strained to the point of no communication when venture failed.

Lost many close friendships, avoided disclosing venture's fate to friends. Stopped attending weekly lunch with friends because of dire financial circumstances.

\section{Physical/psychological consequences}

Was depressed \& did not come out of his

bedroom for two weeks because venture was "his baby". Lost appetite, vomited after meals for a month due to stress.

Felt stressed \& became quite short tempered Started drinking more alcohol to cope.

Was very stressed because he failed his family by creating the financial hardship they had to endure.

Felt emotionally drained \& physically exhausted. Had constant anxiety due to concern for husband who was unemployed due to failure.

Experienced intense grief similar to losing one's life partner through death or divorce.

Professionally humiliated and embarrassed by failure, missed opportunities to introduce this innovative product for large-scale use.

Venture failure was so stressful that it triggered premature menopause \& thyroid disorder. 
Table 3

\section{After failure: Career activities and enhanced resilience}

\begin{tabular}{|c|c|c|}
\hline Participant & Career decisions \& activities & Enhanced resilience (quotes) \\
\hline Luke & $\begin{array}{l}\text { Started new consulting venture that } \\
\text { specialized in mentoring entrepreneurs }\end{array}$ & $\begin{array}{l}\text { "Anything that causes stress, I eliminate it. If this business would show signs of failure, I would } \\
\text { just kill it rather than being emotionally attached to it \& destroy everything else. The business } \\
\text { means nothing if one cannot wake up in the morning and be happy." }\end{array}$ \\
\hline Hayden & $\begin{array}{l}\text { Pursued post graduate qualification in } \\
\text { business }\end{array}$ & "I am not scared anymore of any stressful or challenging situations." \\
\hline Ethan & $\begin{array}{l}\text { Earned income from recycling, working } \\
\text { toward re-starting the failed venture }\end{array}$ & "I now look at life a little bit differently and take things a little easy." \\
\hline Uma & Employed full time as a camp manager. & $\begin{array}{l}\text { "Sometimes you need the tough times [like failure] because that is when you grow as a person } \\
\text { \& learn how to cope with difficult things in life." }\end{array}$ \\
\hline Morgan & $\begin{array}{l}\text { Employed full time as a management } \\
\text { consultant }\end{array}$ & $\begin{array}{l}\text { "Losing the business made me more resilient to cope with the loss of my wife. I picked myself a } \\
\text { lot quicker when I experienced that major loss." }\end{array}$ \\
\hline Francesca & $\begin{array}{l}\text { Returned to scientific research and } \\
\text { writing }\end{array}$ & $\begin{array}{l}\text { "I would be ungrateful to an extraordinary degree to not recognise that I have been hugely } \\
\text { blessed in my life so I will not ruin that sense of blessing by whinging even though I do feel } \\
\text { betrayed \& partially responsible for failure." }\end{array}$ \\
\hline Natalie & $\begin{array}{l}\text { Employed full time as office } \\
\text { administrator \& looking for suitable } \\
\text { partner to start another venture }\end{array}$ & $\begin{array}{l}\text { "I am more resilient to issues in my life now. I could move on from failure \& have learnt to } \\
\text { juggle multiple demands so failure does not break everyone's spirit." }\end{array}$ \\
\hline
\end{tabular}

